\title{
EFFECTS OF CHILD POVERTY ON CHILD LABOUR AND DEPRIVATION AMONG RURAL FARMING HOUSEHOLDS IN ENUGU STATE, NIGERIA
}

\author{
Emmanuel Ejiofor OMEJE * (D), Benjamin Chiedozie OKPUKPARA (iD, Eberechukwu Johnpaud \\ IHEMEZIE
}

Address:

Department of Agricultural Economics, Faculty of Agriculture, University of Nigeria Nsukka, Enugu State, Nigeria.

* Corresponding Author's email: ejiofor.omeje@unn.edu.ng

\begin{abstract}
Both government and non-governmental organisations have been making efforts in the fight against the menace of child labour, child poverty and deprivation. Despite these efforts, $70 \%$ of world's child labour still work in agricultural sector. This study examined the nexus and impact of child poverty, deprivation and other socio-economic variables on child labour among rural farming households in Enugu State of Nigeria. Data for the study were collected using survey research design with the aid of structured questionnaire and interview. Descriptive statistics and multinomial logit regression was applied for data analysis. The result of the study shows that majority $(92 \%)$ of the farming households were engaged in crop farming, majority (69\%) of the children aged between 4 and 17 combined both schooling and agricultural labour. For children who were completely out of school, $5 \%$ we found to be idle while $16 \%$ engaged in agricultural labour. A significant number of children were engaged in agricultural labour, and $62.3 \%$ of them had access to primary school only. About $49.4 \%$ of children cannot obtain primary health services. Age, household size and gender of children had positive and significant $(\mathrm{p}<0.10)$ relationship with child labour. We recommended a redesign of poverty alleviation programmes for rural active farmers and public schools make attractive, accessible and affordable in the rural areas.
\end{abstract}

Keywords: child labour, child poverty, rural farming households, Nigeria

JEL: R13 R23, R51

\section{INTRODUCTION}

It is alarmingly worrisome that agricultural sector holds about 70 per cent of world's child labour (UNICEF, 2011). The cause of this abysmal situation may be partly due to the prevalent poverty level among rural households (Okpukpara and Odurukwe, 2006). As more children engaged in agricultural labour, it is expected to increase agricultural productivity and possibly reduce child poverty momentarily but may cause more harm to the future of the children by depriving them access to basic education, social protection, sanity to life and consequently trap them in the vicious circle of poverty in the long run. The interpretation of child labour from International Labour Organization (ILO) standards as contained in Conventions 138 and 182 means all children below 12 years of age working in any economic activities and those children between 12 and 14 engaged in more than light works. According to UNICEF (2011), an estimated 246 million children are engaged in child Labour in the world, with over $70 \%$ involved in agricultural labour. In Nigeria, about 70 per cent of its rural population are engaged in agriculture and grossly characterized by poverty and low income (Okunmadewa and Omonona, 2006; Omeje and Okoye, 2013). All tangible farming works and operations undertaken by labourers in the sector are referred to as agricultural labour. An individual is therefore said to be an agricultural labourer if the person derives more than 50 per cent of his or her annual income from agricultural sources (Reddy $\boldsymbol{e t}$ al., 2009) further classified agricultural labour into farmer's own labour, family labour, and hired labour. Hired labour could further be classified according to the nature of its remunerations.

It is therefore, imperative to approach this study from the perspective of establishing linkages among labour, poverty and deprivation of children in agricultural labour since the sector holds almost 70 per cent of child labour. Everywhere in the world and specifically in Africa where family labour is perceived to be traditional in agriculture, no one would reasonably oppose the engagement of children in such economic activities provided that the work does not negatively affect their health, education and development. Such light work is not only recommended for proper upbringing of the child especially in Nigeria but is also permitted from the age of children of 12 years under ILO Convention No.138.

Poverty among other factors is responsible for such huge number of children involvement in agricultural labour. According to UNICEF (2011), child poverty entails a child who is deprived of the material resources needed to develop and thrive, leaving them unable to enjoy their rights, achieve their full potentials, or participate as full and equal member of the society (UNICEF, 2009). Poverty leads to deprivation and child labour. Most often, those found to have led their children into hard labour do so as a coping strategy. Child Poverty level could be estimated from the amount of money spent daily or based 
on deprivations from these dimensions such as: safe drinking water, sanitation, housing, health and nutrition. According to UNICEF (2009), child poverty is not only money metrics but also multidimensional. According to sanders (2003), poverty entails lack of needed resources which causes social exclusion. Individuals, families and groups in the population can be said to be in poverty when they lack the resources to obtain the type of diet needed, participate in social activities and have the living conditions and amenities which are customary, or at least widely encouraged of children, or approved, in the societies to which they belong. This paper therefore examined the incidence and interconnectivity of child labour, poverty and deprivation among rural farmers in Nigeria. It investigated the engagement of children between 4-14years in agricultural labour and estimates child poverty among children of 4-14years using International Poverty Line (IPL) bases on current World Bank Purchasing Power Parity (PPP). Literature on child labour and poverty considered from the (agricultural) sectoral perspective in Nigeria are few. Ofuoku $\boldsymbol{e t}$ al. (2014) determined the level of child labour involvement in arable crop farming and found that children participated in field preparation, planting, weeding, pesticide, fertilizer and herbicide application, harvesting, transportation and processing. Many (43.33\%) of the children combined schooling with farming operations. The decision of the farming, household heads to use child labour was influenced by socioeconomic variables such as gender, age, level of education, household size, farm income, farm size, culture, economic factors and political factors. Closely too, Okpukpara and Odurukwe (2006), reported a two-way link between child labour and household poverty in Nigeria but the study did not specifically investigate what transpired within the agricultural sector only. However, various studies conducted on poverty in Nigeria in the past include Onah (1996), Ogwumike and Ekpeyong (1996), Anyanwu (1997), Odusola (1997), Englama and Bamidele (1997) and many by UNICEF and other organizations. None of them quantified the specifics of child labour and poverty and the factors that influence them within agricultural sector. Others include the Global Study on Child Poverty and Disparity by UNICEF which employed the use of the MICS 2007 to examine well-being of children and introduced Alkire and Foster dual cut-off identification methodology for poverty classification across different sectors and highly polarized poverty gaps without recourse to the specifics of rural agrarian societies. This paper adopted the IPL based on PPP by World Bank to classify the focused group into categories. The threshold was pegged at the World Bank's recommended USD1.90/person/day. The encumbrances and ambiguities associated with estimating poverty in the rural areas were nailed by valuing the alternative costs of all the food, water, and other essential commodities sourced by the households without buying them. Of course, some of the rural farmers produce their own food and buy only little from the market, source clean water from streams and make provisions for other essential needs without going to market. So, this study did not leave out the values of what they produced and provided by themselves for household consumptions.

According to Omeje et al. (2019), Nigeria is one of the developing economies with significant expenditures on agricultural protection through interest and exchange rates differentials, price mechanisms, input subsidies, researches, embargos and regulations promulgated in various protectionist policy reforms, projects and programmes. The reason for such protection policy and other interventions as shown in Figure 1, was to improve the livelihoods of the rural farmers and their households. Apart from the special interventions in agriculture, governments and non-governmental organizations have spent fortunes and rolled out policies promulgated towards reducing these global challenges of child labour, poverty and deprivations but those 'one-for-all approaches' or policies seem to be inappropriate in dealing with specific sectors and locations with varying degrees of custom, norms, political, environmental and socioeconomic factors, hence the situation worsens. The peculiarities of agricultural labour and factors affecting farming households especially in the rural areas demand that a new and distinct approach other than a blanket solution be given a trial in this our fight against child deprivations.

The broad objective of this paper is to examine the interconnectivity of child labour, child poverty and deprivation among rural farming households in Enugu State, Nigeria. The specific objectives are to:

describe the socioeconomic and other characteristics of the farming households,

identify various forms of child labour in the sector, profile poverty statuses of the children (4-14years), and

estimate the effect of child poverty and other socioeconomic characteristics on child labour.

\section{DATA AND METHODS}

\section{The Study Area}

The study area is Enugu State in south-eastern part of Nigeria. Enugu State is located between latitude 6.459964, and the longitude is 7.548949 with the GPS coordinates of $6^{\circ} 27^{\prime} 35.8704^{\prime \prime} \mathrm{N}$ and $7^{\circ} 32^{\prime} 56.2164^{\prime \prime} \mathrm{E}$. It has a total of seven thousand, one hundred and sixty-one kilometre square $\left(7,161 \mathrm{Km}^{2}\right.$ or 2, 764.9 sq.m) land and lies south of Benue and Kogi States as well as east of Anambra State.

It is also bounded in the east of Ebonyi State and South by Abia State. The state has a climate marked with two major seasons including rainy season which lasts between April and October; and dry season lasting from November to March (ESG, 2010). $70 \%$ of its rural population are engaged in agriculture, with about $18 \%$ and $12 \%$ of its working rural population engaged in trading and services (Omeje and Okoye, 2013). The state has good soil-land climatic condition all year round, making it suitable for agriculture, sitting at about 223 meters above sea level and the soil is well drained during rainy season (ESG, 2010).

\section{Sampling Techniques}

This study employed purposive and multistage random sampling techniques for selecting the respondents (First 2 
stages were purposive while last 2 stages were random). Purposively, the six agricultural zones in Enugu State were selected for convenience. One Local Government Area (LGA) was selected from each of the 6 agricultural zones making a total of 6 LGAs. These LGAs were selected using purposive random sampling to ensure that only predominantly rural farming households were the respondents. From the six (6) selected LGAs, five (5) communities were selected using systematic random sampling to make up 30 communities. Lastly, fifteen (15) households were also selected using systematic random sampling from each of the 30 communities, making a total of 450 rural farming households. These respondents comprised of both faming households with/and those without child or children between 4 to 5 years.

\section{Data Collection}

The data used for analysis in this study was collected from primary source between September 2017 and February 2018. The data were gathered by the researchers using a structured questionnaire and interview schedule administered on the rural households' heads and children between 4 and 14 years. The socio-economic characteristics used in the study include: age of children, gender of children, marital status, and years of education of heads, household size, poverty status, group membership and farm size.

\section{Data Analysis}

Objectives 1-3 were realized using descriptive statistics, and objective 4 was realized using multinomial logit regression model. The model used is specified by the Eq. $1-4$.
$\operatorname{Pr}(y=1)=\frac{1}{1}+\lambda^{X B(2)}+\lambda^{X B(3)}+\lambda^{X B(4)}+$ $\lambda^{X B(5)} \ldots+\lambda^{X B(n)}$

$\operatorname{Pr}(y=2)=\frac{\lambda^{X B(2)}}{1}+\lambda^{X B(2)}+\lambda^{X B(3)}+\lambda^{X B(4)}+$
$\lambda^{X B(5)} \ldots+\lambda^{X B(n)}$

$\operatorname{Pr}(y=3)=\frac{\lambda^{X B(3)}}{1}+\lambda^{X B(2)}+\lambda^{X B(3)}+\lambda^{X B(4)}+$ $\lambda^{X B(5)} \ldots+\lambda^{X B(n)}$ $\operatorname{Pr}(y=4)=\frac{\lambda^{X B(4)}}{1}+\lambda^{X B(2)}+\lambda^{X B(3)}+\lambda^{X B(4)}+$
$\lambda^{X B(5)} \ldots+\lambda^{X B(n)}$

Where:

$\operatorname{Pr}(\mathrm{Y}=1)$ neither schooling nor engaged in child labour (idle group),

$\operatorname{Pr}(\mathrm{Y}=2)$ child labour only,

$\operatorname{Pr}(\mathrm{Y}=3)$ schooling only and,

$\operatorname{Pr}(\mathrm{Y}=4)$ child labour and schooling combined.

\section{RESULTS AND DISCUSSION}

\section{Socioeconomic Characteristics of the Farming Households}

The socioeconomic characteristics and other relevant statuses of the respondent are discussed. Majority (92\%) were engaged in crop farming; $75 \%$ were married; $31 \%$, $33 \%, 21 \%$ and $15 \%$ had no formal education, primary, secondary and tertiary education respectively. Among the households, many of them had family sizes of 12-14 (5\%), 8-11 (22\%), 0-3 (25\%), and 4-7 (39\%). Both the age distribution and household size suggest that many of them are still in their active years of reproduction and faming.

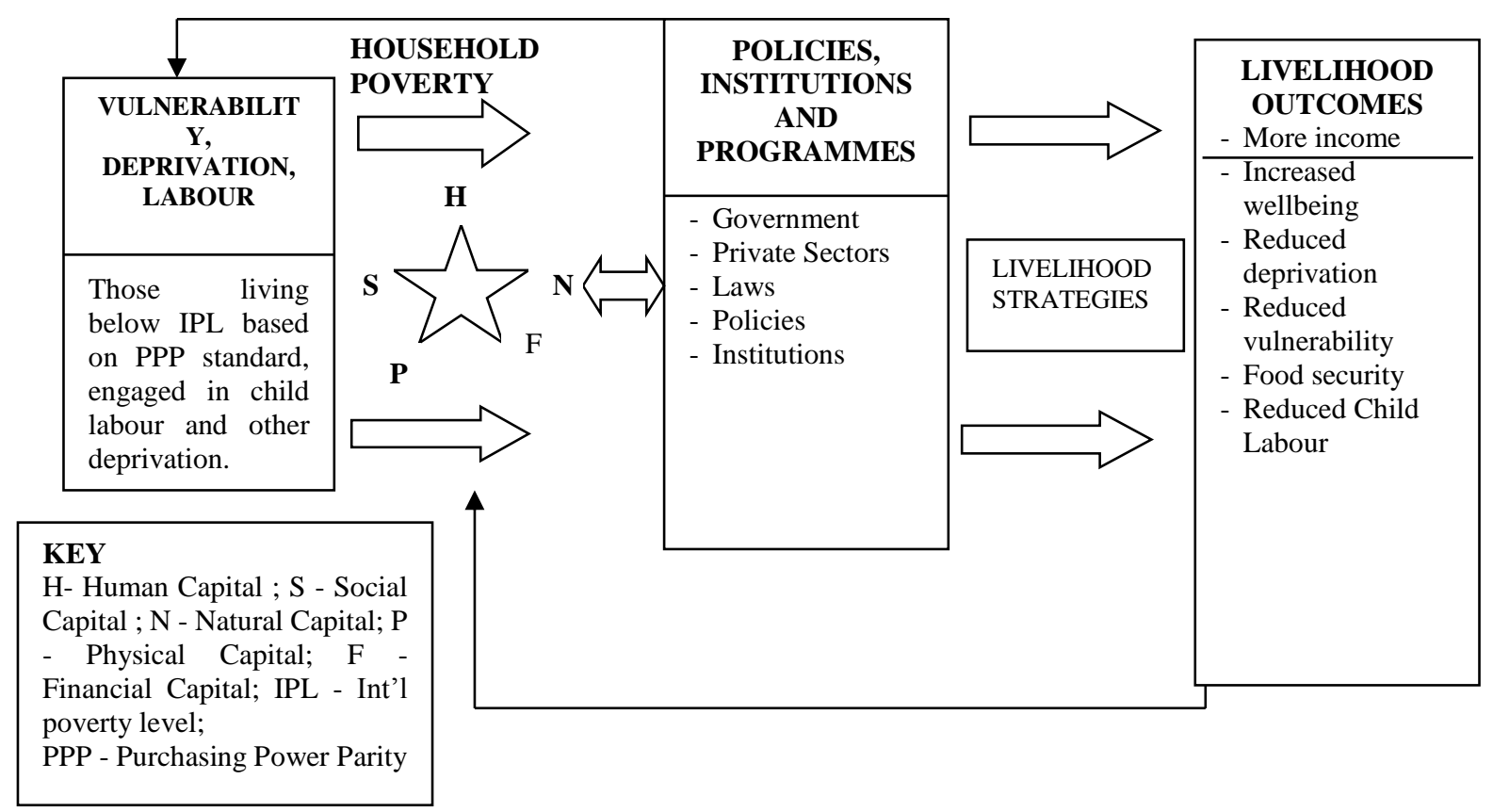

Figure 1: Conceptualization of child labour-poverty Framework

Source: Adapted from Department for International Development (DFID, 2003) 


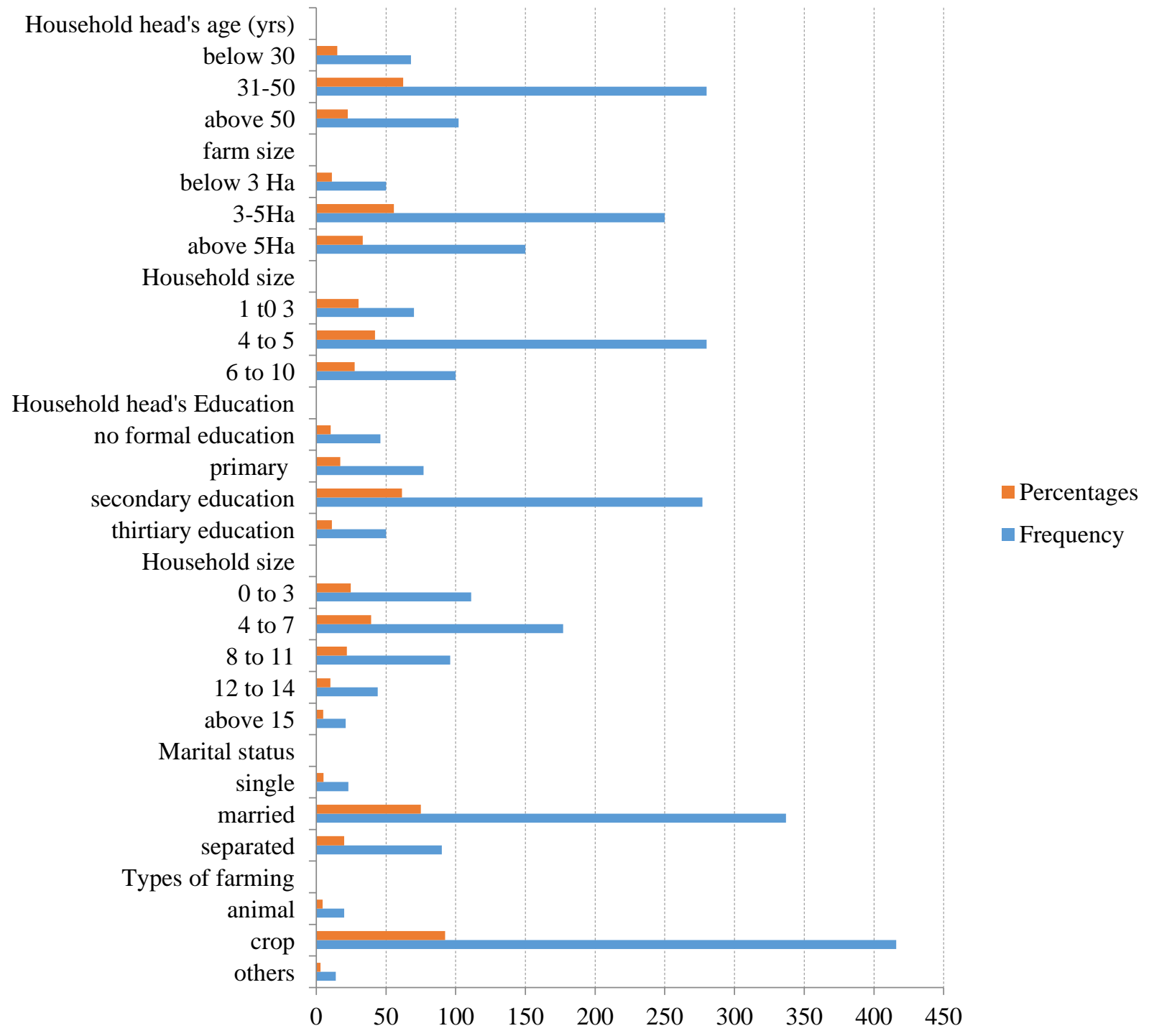

Figure 2: Socioeconomic characteristics of the farming households in the sample Source: Own work based on field survey, 2018.

Groups and Forms of Children engagement in Agricultural Labour

Out of the 450 sampled rural farming households, 36 percent of them had children between 04-14 years of age, which is our major concern in this study (Table 1). Households without children were 82, and those households with children between $0-3$ and above 14 yearschildren were 80 and 126 respectively.

Majority (69\%) of the children combined both schooling and agricultural labour. However, some children $(21 \%)$ were completely out of school of which $5 \%$ was completely idle (i.e., not engaged in labour and agriculture labour) (Figure 2). Out of all the respondents, $36 \%$ (162) of the households had children aged between 4 and 14 (Table 1). 128 respondents were deeply engaged in agricultural labour.

Child's family owned most of the labour contributed by children (Table 2). Family labour took about $40.6 \%$, hired labour $39.1 \%$, own labour $4.7 \%$ and combined family and hired labour $15.6 \%$. All paid labour (44.7\%), was further grouped into four categories including piece wage $(85.2 \%)$, time wage $(0.00 \%)$, kind wage $(7.4 \%)$ and cash wage $(7.4 \%)$.

\section{Child Poverty and deprivation profiles}

Our results revealed that slightly more than halve of the rural farming households $(51.2 \%)$ still live in poverty using the IPL standard based on World Bank PPP (Table 3). However, poverty is correlated with level of deprivation from certain social amenities which are more pronounced in the rural area than urban. This study further showed that out of the 162 households, only $62.3 \%$ agreed to have had good access to primary school while $37.7 \%$ felt deprived of primary education. $50.6 \%$ agreed to have accessed primary health services while 48.8 felt deprived. Barely half of the children under review are living below poverty line (Table 3), while $37.7 \%$ and $49.4 \%$ of the children had no access to primary school and primary health centres, respectively (Table 4). 
Table 1: Grouping of child labour according to labour intensity

\begin{tabular}{lrr}
\hline Households' children data & FrequencyPercentage \\
\hline Household with kids 4-14years & 162 & 36 \\
Household without kids at all & 82 & 18.2 \\
Household with kids 0-3 years & 80 & 17.7 \\
Household with kids above 14years & 126 & 28 \\
Intensity of child labour, N=162 & 162 & 100 \\
Idle children & 8 & 5 \\
Children engaged in labour only & 16 & 10 \\
Children engaged in labour and schooling & 112 & 69 \\
Children engaged in school only & 26 & 16 \\
\hline
\end{tabular}

Source: Own work based on field survey, 2018.

Table 2: Grouping of children according to ownership of the farms where child labour was engaged

\begin{tabular}{lll}
\hline $\begin{array}{l}\text { Agric. } \\
\text { labour, N=128 }\end{array}$ & Frequency & Percentage \\
\hline Family labour only & 52 & 40.6 \\
Hired labour only & 50 & 39.1 \\
Own labour only & 6 & 4.7 \\
Family and hired labours & 20 & 15.6 \\
\hline
\end{tabular}

Source: Own work based on field survey, 2018.

Table 3: Child poverty profile of households bearing child labourers in line PPP based IPL

\begin{tabular}{lll}
\hline $\begin{array}{l}\text { Poverty status of HH } \\
\text { N 162 }\end{array}$ & Frequency & $\begin{array}{l}\text { Percentage } \\
\text { of children }\end{array}$ \\
\hline In poverty & 83 & 51.2 \\
Not in poverty & 79 & 48.8 \\
\hline
\end{tabular}

Source: Own work based on field survey, 2018.

Table 4: Child deprivation profile of households bearing child labourers

\begin{tabular}{lll}
\hline $\begin{array}{l}\text { Child deprivation indexes, } \\
\text { N-162 }\end{array}$ & Frequency & $\begin{array}{l}\text { Percentage } \\
\text { of children }\end{array}$ \\
\hline $\begin{array}{l}\text { Access to primary school } \\
\text { Yes }\end{array}$ & 101 & 62.3 \\
No & 61 & 37.7 \\
Access to primary & & \\
health centres & & \\
Yes & 82 & 50.6 \\
No & 80 & 49.4
\end{tabular}

Source: Own work based on field survey, 2018.

Effect of child poverty, deprivation and socioeconomic characteristics on child labour

Child labour among children were grouped into four categories: category one - those who were neither in school nor in child labour; category two - those who were engaged in child labour only; category three - those who were in school only and; category four - those who were in school and engaged in child labour simultaneously. However, category one (those who were neither in school nor in child labour) was used as the base category $\left(\mathrm{P}_{\mathrm{r}}\left(\mathrm{Y}_{1}\right)\right.$ $=0$ ) in the analysis. The following variables were used as the political, environmental and socio-economic characteristics: age of children, gender of children, marital status, household size, and years of education of household heads, poverty status, group membership, and proximity to hospital and farm size.
Results of how rural households' political, environmental and socio-economic characteristics influenced child labour engagement among rural farming households in Enugu State are presented in Table 5. For the whole sample, the following variables: age of children, gender of children, marital status of the household heads, household size, group membership, proximity to hospital and farm size were statistically significant.

\section{Age of children}

Age of children had a positive and significant $(\mathrm{p}<0.10)$ relationship with the probability to engage in child labour (Table 5). This implies that an increase in age of children among the households would increase the probability of involvement in child labour and schooling category.

\section{Gender of children}

Gender of children (male children) had positive and significant influence $(\mathrm{p}<0.10)$ on their probability to engage in child labour (child labour only) among the rural farming households of Enugu state. This is expected since male children are more likely to engage in child labour both in rural and urban areas.

\section{Household Size}

Household size had positive and significant $(p<0.01)$ relationship with the probability of children been engaged in agricultural labour (Table 5). Muturi (1994) showed that a relationship exists between child labour and family size. This implies that further increase in the number of people in the rural households would lead to an increase in number of children in child labour (child labour only). This may be true since increase in household size would lead to demand for more food, wellbeing, health services, and poverty the people may become more vulnerable to poverty if household size increases without commensurate increase in livelihood outcomes. This is also in line with the results of the DFID (2003).

\section{Poverty Level}

In this analysis, poverty level had negative but significant relationship at $5 \%$ level of probability $(\mathrm{p}<0.05)$ with both 'schooling and child labour' category. This suggests that as poverty level of the households increases, more children were made to combine their schooling with agricultural labour. This is in accordance with the a priori expectation and that of Naeem et al. (2011) which found that children work mainly due to poverty and that poor parents are forced to send their children to work instead of school. 
Table 5: Effect of child poverty, deprivation and socioeconomic characteristics on child labour

\begin{tabular}{|c|c|c|c|}
\hline $\begin{array}{l}\text { Explanatory } \\
\text { Variables }\end{array}$ & $\begin{array}{l}\text { Child labour } \\
\text { only }\end{array}$ & $\begin{array}{l}\text { Schooling } \\
\text { only }\end{array}$ & $\begin{array}{l}\text { Combined child labour } \\
\text { and schooling }\end{array}$ \\
\hline \multirow[t]{2}{*}{ Age of children } & 0.03 & 0.323 & $0.0828 * * *$ \\
\hline & $(0.309)$ & $(408.33)$ & $(0.0293)$ \\
\hline \multirow[t]{2}{*}{ Gender of children $(1 / 0)$} & $4.56^{* * *}$ & 29.101 & 0.365 \\
\hline & $(1.097)$ & $(7713.959)$ & $(0.814)$ \\
\hline \multirow[t]{2}{*}{ Marital status } & $0.98 * *$ & 9.726 & -0.158 \\
\hline & $(0.460)$ & $(4294.485)$ & $(0.448)$ \\
\hline \multirow[t]{2}{*}{ Years of education of heads } & -0.04 & 0.729 & 0.632 \\
\hline & $(0.077)$ & $(580.067)$ & $(0.698)$ \\
\hline \multirow[t]{2}{*}{ Household size } & $0.35 *$ & 2.868 & 0.152 \\
\hline & $(0.177)$ & $(1680.15)$ & $(0.1504)$ \\
\hline \multirow[t]{2}{*}{ poverty status $(1 / 0)$} & -0.0000 & $-1.03 \mathrm{e}$ & $-0.0000 * *$ \\
\hline & $(0.0000)$ & $(0.002)$ & $(0.0000)$ \\
\hline \multirow[t]{2}{*}{ Group membership (1/0) } & $-3.54 * * *$ & -43.298 & $2.00735 * * *$ \\
\hline & $(10.946)$ & $(4884.51)$ & $(0.917)$ \\
\hline \multirow[t]{2}{*}{ Proximity to hospital (1/0) } & $0.00 * * *$ & 0.000 & $0.0000 * * *$ \\
\hline & $(0.000)$ & $(0.0343)$ & $(0.0000)$ \\
\hline \multirow[t]{2}{*}{ Farm size (ha) } & $4.30 * * *$ & 90.45 & $4.3816^{* * *}$ \\
\hline & $(1.348)$ & (17355.34) & (1.277) \\
\hline \multirow[t]{2}{*}{ Constants } & $-9.02 * * *$ & 65.604 & $-9.59 * * *$ \\
\hline & $(12.445)$ & $(4880.36)$ & (2.518) \\
\hline
\end{tabular}

Chi square $\left(\mathrm{X}^{2}\right)-(22)=217.97$

Prob $>\mathrm{X}^{2}=0.0000$

Pseudo $\mathrm{R}^{2}=0.4918$

Note: $* * *$ and $* * *$ denote significant at the $10 \%, 5 \%$ and $1 \%$ levels respectively; $\operatorname{Pr} \mathrm{y}=1$ the base category; the figures in parentheses are robust standard errors.

Source: Own work based on field survey, 2018.

\section{Group membership}

Those children whose household heads belonged to one or more groups like Isusu, age of grade, political parties and cooperatives had negative and significant $(\mathrm{p}<0.10)$ relationships with 'child labour' category and in both 'schooling and child labour' category which was positive and significant at $10 \%$ levels of probability (Table 5). This suggests that those households whose heads were engaged in social and political groups seem to be more aware of the dangers of child labour and it reflected in their lifestyle.

\section{Proximity to hospital}

Proximity to hospital had negative and significant relationship at $1 \%$ level of probability with 'child labour' category. This implies that as the proximity to hospital of the respondents is increasing, their tendency to encourage child labour reduces. This suggests that as the households were saving more from sicknesses and treatments as a result of availability of health centres, more children were saved from joining agricultural labour.

\section{Farm size}

Farm size had positive and significant relationship with both categories of child labour ('child labour only' and 'schooling/child labour') (Table 5). This implies that as the farm size increases, the need for child labour also increases among the rural farming households.

\section{RECOMMENDATIONS AND CONCLUSION}

To proffer workable policies and address the challenges identified in this research, the following recommendations are presented for action:

- Since over $70 \%$ of the rural population is engaged in agriculture, and studies have shown that $70 \%$ of child labour is found in agricultural sector, it is pertinent that UNICEF and stakeholders consider a change from the current 'one-for-all' policy approach to a more specific policy for the rural farming households towards the fight against child labour. This will go a long way in reducing this huge number of children engaged in agricultural labour.

- Deliberate efforts should be made to target rural (agriculture) extension officers, religious and community cum opinion leaders with appropriate programs, workshops and trainings that can improve their understanding of child welfare, so that they can also educate other rural farmers.

- Access to both primary health care (PHC) and primary schools were put at $50.6 \%$ and $62.3 \%$ respectively. Both health and education ministries and agencies should try to improve access to these facilities by making PHC more affordable and primary schools attractive.

- Sequel to the result that as more household heads acquire basic education, they tend to pull their children out from child labour. Ministry of education should reconsider adult education policy for the rural people since education is pivotal in this fight.

- Finally, poverty has direct link with child labour 
and deprivation. Ministry of agriculture should address the poverty issues among rural farmers by designing special agricultural protection policy for them. This can be done through some agricultural protection instruments such as subsidies and market/price bylaws.

This study has examined the nexus and impact of child poverty, deprivation and other socio-economic variables on child labour among rural farming households in Enugu State of Nigeria. In most rural African communities where poverty is prevalent, child labour is often viewed as an economic activity to augment family income. However, this has serious implications on child growth and development, as it could affect their health and impinge on their education. This study found that there is an inverse relationship between poverty and child schooling. As the poverty status of the family or household deepens, the likelihood of sending their children to engage in child labour also increases. Again, the findings of the study suggest that the male child had more probability to engage in child labour. All these have policy implications for the fight against child labour and deprivation in Nigeria. First, a blanket 'one size fits all' policy may not be effective in eradicating the menace.

\section{REFERENCES}

ANYANWU, J.C. (1997). Poverty in Nigeria: Concepts, Measurement and determinants. In: Proceedings of the Nigerian Economic Society Annual Conference on Poverty Alleviation in Nigeria 1997. Nigerian Economic society, Ibadan. PP. 93-120

DFID - DEPARTMENT FOR INTERNATIONAL DEVELOPMENT (2003). Sustainable livelihoods: guidance sheet prepared by the DFID, the British Government's department responsible promoting development and reduction of poverty. http://www.livelihoodscentre.org/documents/20720/1001 45/Sustainable+livelihoods+guidance+sheets/8f35b59f8207-43fc-8b99-df75d3000e86

ENGLAMA, A., \& BAMIDELE, A. (1997). "Measurement Issues in Poverty." In the Annual Conference Proceedings of the Nigerian Economic Society (NES): Poverty in Nigeria, pp. 141-158.

ESG - ENUGU STATE GOVERNMENT (2010). Learn about Enugu State, Nigeria. Retrieved from http://www.ngex.com/nigeria/places/states/enugu.htm 2/10/2019

KATHURE, M. G. (2016). Child labour in rural and urban Kenyan Settings: A comparative study of Kakuzi Location, Murang'a County and Kibera Slum, Nairobi County. A thesis submitted to the Department of Sociology and Social Work, University of Nairobi. Accessed online on 5/10/2019 from http://erepository.uonbi.ac.ke/bitstream/handle/11295/97 321/Mugo\%20Grace\%20Kathure\%2C\%20MA\%20Thesi s.pdf? sequence $=1 \&$ is Allowed $=\mathrm{y}$

NAEEM, Z., SHAUKAT, F., \& AHMED, Z. (2011). Child labor in relation to poverty. International Journal of Health Sciences, 5(2 Suppl 1), 48-49.
NPC - NATIONAL POPULATION COMMISSION (2017). Nigeria's current estimated population. Accessed online through population.gov.ng on 6/2/2018.

ODUSOLA, A. F. (1997), Poverty in Nigeria: An eclectic appraisal: Poverty Alleviation in Nigeria, Selected Papers for the 1997 Annual Conference of Nigerian Economic Society. https://www.nigerianeconomicsociety.org

OFUOKU, A. U., IDOGE, D. E., \& OVWIGHO, B. O. (2014). Child labor in agricultural production and socioeconomic variables among arable farming households in Nigeria. Journal of Rural Social Sciences, 29(2), 2014, pp. 67-81. Southern Rural Sociological Association.

http://journalofruralsocialsciences.org/pages/Articles/JRS S\%202014\%2029/2/JRSS\%202014\%2029\%202\%2067$\underline{81 . p d f}$

OGWUMIKE, F.O., \& EKPENYONG, D. B. (1995). Impact of structural adjustment policies on poverty in Nigeria. Final Report, AERC, Nairobi, May.

OKUNMADEWA, F.Y., YUSUF, S.A. AND OMONONA, B.T. (2006). Social capital and poverty reduction in Nigeria revised report submitted to Africa Economic Research Consortium (AERC) Nairobi, Kenya. https://sarpn.org/documents/d0002275/Social_capital_A ERC_Sept2005.pdf

OKPUKPARA, B. C, \& ODURUKWE, N. (2006). Incidence and determinants of child labour in Nigeria: implications for poverty alleviation. AERC research paper 156, Nairobi: AERC. http://opendocs.ids.ac.uk/opendocs/handle/123456789/26 67

OMEJE, E. E., \& OKOYE, C. U. (2013). Critical constraints limiting the engagement of graduates of agriculture in commercial agricultural production in Nigeria. African Journal of Development and Research, AJDRE, vol.No.2, 2013. (Pages 108-116). https://oer.unn.edu.ng > download > critical-constraintslimiting-the-engage...

OMEJE, E. E. (2014). Effects of microcredit on the livelihood of rural households in Enugu state, Nigeria. An M.Sc dissertation submitted to the Department of Agricultural Economics, University of Nigeria, Nsukka. https://oer.unn.edu.ng/read/effects-of-micro-credit-onthe-livelihood-of-rural-households-in-enugu-state-

nigeria-2

OMEJE, E. E., ARENE, C. J., \& OKPUKPARA, B. C. (2019). Impact of agricultural protection on agricultural growth in Nigeria: political economy perspective (19802016). Review of agricultural and applied economics, ISSN 1336-9261, XXII (number 1, 2019): 41-50, DOI: $10.15414 /$ raae.2019.22.01.41-50

ONAH, F. E. (1996). Post Adjustment Policies toward Poverty Alleviation in Nigeria. Nigerian J. Econs. Social Stud., 38 (1, 2, 3) pp. 97-218.

SAUNDERS, P. (2003). Can Social Exclusion Provide a New Framework for Measuring Poverty? SPRC Discussion Paper No. 127, October 2003. The Social Policy Research Centre. University of New South Wales, Sydney NSW 2052, Australia. ISSN: 1447-8978, ISBN: 0 733420753. 
UNICEF - UNITED NATIONS CHILDREN'S FUND (2009). United Nations Children's Fund, “Millennium Development Goals. Eradicating extreme poverty and hunger" [online] http://www.unicef.org/spanish/mdg/poverty.html, 2009 UNICEF - UNITED NATIONS CHILDREN'S FUND (2011). Unicef: child labour factsheet. Accessed online on 27/03/2018 on https://www.unicef.org/protection/files/child_labour.pdf 